УДК 339.13.009.6(477)

(C) 2014

Урусова З. П., Ярмош В. В., кандидати економічних наук,

Урусов А. А., студент

Запорізький національний університет

\title{
ПРОБЛЕМИ ТА ПЕРСПЕКТИВИ РОЗВИТКУ РИНКУ ФІНАНСОВИХ ПОСЛУГ В УКРАЇНI
}

\section{Рецензент - доктор економічних наук, професор Д. І. Бабміндра}

\begin{abstract}
Ринок фінансових послуг є ринком, на якому відбувається обмін фінансовими ресурсами, надання кредиту й мобілізачія капіталу. Об'єктивною підставою функиіонування фінансового ринку є неспівпадіння потреби в фінансових ресурсах із наявністю джерел задоволення иієї потреби. Ринок фінансових послуг один із механізмів забезпечення конкурентоспроможності економіки країни, поскільки розподіл фінансових ресурсів на ньому відбувається на конкурентній основі, щзо дає можливість спрямувати інвестиційні потоки у найбільш привабливі сетменти економіки й тим самим сприяти економічному зростанню. Саме тому у статті розглянуті й визначені фактори, щуо є визначальними для підвищення конкурентоспроможності Украӥни на ринку фінансових послуг у глобальному та регіональному масштабі.
\end{abstract}

Ключові слова: фінансовий ринок, фінансова політика, фондовий ринок, прямі інвестииї, циіннi nапери.

Постановка проблеми. Становлення й розвиток ринку фінансових послуг є однією 3 передумов ефективного функціонування всіх сфер i ланок економіки країни.

Пройшовши етапи виникнення та становлення, фінансовий сектор України знаходиться у стадії жорсткої конкурентної боротьби як з боку українських, так й іноземних фінансових установ.

Кожен 3 учасників ринку вступає в складну боротьбу за ресурси, прибутки та можливості. Крім того, спостерігається тенденція до універсалізації фінансових установ, що збільшує конкуренцію й вимагає шукати нові напрями розвитку власного бізнесу.

Особливо актуальною стає взаємодія фінансових установ, зокрема банків та страхових компаній, як найактивніших учасників фінансового ринку, здатних реально впливати на нього.

Взаємодія банків і страхових компаній може набувати різних форм, з-поміж яких банківське страхування, страхування банківських ризиків та надання страховим компаніям банківських послуг - розміщення коштів, розрахункове обслуговування та ін.
Аналіз основних досліджень і публікацій, у яких започатковано розв'язання проблеми. Дана проблема передусім має загальнодержавне значення, тому даній тематиці нині надається чимало уваги як з боку науковців, так і практиків. Не залишаються осторонь й урядові структури. Значний внесок у розробку питань функціонування фінансового ринку та діяльності комерційних банків на ньому зробили економісти Г. Марковіц, Р. Мертен, Ф. Мишкін, Е. Петерс, В. Андрущенко, О. Білорус, С. Боринець, В. Будкін, О. Гаврилюк, А. Гальчинський та інші.

Серед російських вчених слід виділити роботи А. І. Басова, В. І. Колеснікова, Ю. І. Львова, Я. М. Міркіна, В. С. Торкановского та інших. Однак не всі аспекти окресленої проблеми знайшли відображення в їхніх публікаціях [1-9].

Мета дослідження: розглянути особливості структури вітчизняного фінансового ринку.

Завдання: запропонувати інструменти впливу, а також актуалізувати пріоритетні шляхи розвитку фінансового ринку України.

Результати досліджень. Ринкове середовище визначає існування різних формувань, які охоплюють ринкові елементи та економічні відносини, що пов'язують їх один з одним із урахуванням економічної природи й правових умов. Найбільш типовим $\epsilon$ виокремлення ринків за ознаками суб'єктів та предметів обігу.

У сучасних умовах господарювання консолідація фінансових ресурсів відбувається із застосуванням механізмів та інструментарію фінансового ринку, що разом із прискоренням темпів реформування фінансової сфери значно ускладнює механізми перебігу процесів формування, функціонування й регулювання політики банківських установ, викликаючи нагальну потребу в додатковому дослідженні.

Сьогодні на ринку фінансових послуг склалася низка тенденцій і напрямів розвитку, що суттєво впливають на якість і специфіку послуг фінустанов. До них, зокрема, можна віднести домінування банківського сектора над усіма іншими на фінансовому ринку. Так, фінансовий 


\section{ЕКОНОМІКА}

ринок України розвивається за європейською моделлю [2]. Глобалізація світових економічних процесів та іiі вплив на фінансовий сектор також суттєво позначаються на тенденціях, що панують у фінансовому секторі економіки. Похідними від цього є процеси злиття й поглинання українських фінансових установ іноземними корпораціями, групами компаній, холдингами i т. П. [7].

У зв'язку з процесами глобалізації на міждержавному рівні приймаються угоди про універсалізацію вимог до діяльності фінансових інституцій, посилюється вплив транснаціональних фінансових корпорацій, збільшуються обсяги транскордонного переміщення капіталів.

Важливою закономірністю розвитку сучасного фінансового ринку стала тенденція до універсальності та комплексності фінансових послуг клієнтам. Зі зростанням фінансової освіченості населення зростає зацікавленість у послугах небанківських фінансових установ [2].

Проблема українського ринку фінансових послуг полягає у відсутності в нього фінансових ресурсів для забезпечення інвестиційного попиту 3 боку реального сектора економіки. Відповідно, вирішення цієї проблеми передбачає створення умов, які б давали змогу додатково залучити внутрішні фінансові ресурси, зокрема, заощадження населення та «тіньовий капітал» до інвестиційної діяльності, а також створити привабливі умови для іноземних інвесторів. Отже, залишається проблема мобілізації ресурсів.

Хто може здійснювати мобілізацію фінансових ресурсів i що цьому перешкоджає? Поперше, це банки. Однак банків в Україні занадто багато, тому фінансові ресурси є досить розпорошеними. Крім того значна частина коштів нині перебуває в безготівковій формі, обслуговуючи «тіньовий» капітал, а також у формі заощаджень населення поза банками.

По-друге, акумулюванням та інвестуванням фінансового капіталу займаються різноманітні учасники фондового ринку: інвестиційні компанії та фонди, трастові компанії (довірчі товариства). Вагомими учасниками фондового ринку можуть бути пенсійні фонди. У розвинутих країнах ці заклади останнім часом відіграють усе вагомішу роль в інвестиційній діяльності, акумулюючи значні кошти та інвестуючи ї, в основному, в акції приватних компаній. Банки також $є$ потенційними гравцями на ринку цінних паперів, оскільки останні є привабливим джерелом забезпечення ліквідності [3].

Однак усе це $є$ справедливим за умов розвиненого фондового ринку, якого ми в Україні, на жаль, поки що не маємо. Слабкість фондового ринку України виражається в наступному:

1. Недостатня ліквідність фондового ринку.

2. Переважання державних цінних паперів.

3. Недостатня прозорість діяльності емітентів та професійних учасників ринку.

4. Нерозвиненість правової бази, неадекватність іiі сучасним вимогам діяльності на ринку фінансових послуг.

5. Низький технологічний рівень функціонування ринкової інфраструктури.

6. Низький рівень корпоративної культури.

7. Недостатня обізнаність переважної частини населення $з$ питань фондового ринку [4].

Недостатня ліквідність українського фондового ринку пояснюється малими обсягами фінансових потоків, які обертаються на ньому. Ліквідність фондового ринку визначається тим, наскільки він може забезпечити достатній попит на певні цінні папери. На сьогодні ліквідність фондового ринку досить низька.

Аналізуючи фінансовий ринок України, вітчизняні аналітики влучно зазначають, що «у нас фінансовий ринок замість того, щоб твердо стояти на двох ногах (банківській і фондовій), ... вийшов одноногим із «фондовою милицею». Швидко не побіжиш» $[5,8]$. Банківська система України $є$ найбільш конкурентоспроможною ланкою фінансового сектора економіки України i, відповідно, у ході проведення низки заходів щодо підвищення якості іiі функціонування зможе ефективно діяти в умовах подальшої лібералізації зовнішньоекономічних відносин. До конкретних шляхів розвитку банківського сектора України можна віднести [6]:

- створення сучасного банківського законодавства 3 орієнтацією на законодавство Європейського Союзу та сучасну міжнародну практику;

- перехід банківської системи на систему обліку, що базується на Міжнародних стандартах фінансової звітності;

- створення національної платіжної системи на основі передових комп'ютерних технологій;

- створення й постійне вдосконалення системи банківського нагляду.

Світова фінансова криза змусила переглянути усталені принципи регулювання державою фінансового ринку. Саміт «Групи 20» не лише піддав гострій критиці недооцінку економічної ролі держави, а й вказав на необхідність зростання іiі ролі в регулюванні ринкової економіки, що було чітко зазначено у прийнятій самітом декларації: «Загальнонаціональні інтереси задають формат для реалізації приватних інтересів, ... чим біль- 


\section{ЕКОНОМІКА}

ше ринків, тим більше потрібно держави, тим більше лягає відповідальності на державні інститути за вектор економічного і соціального розвитку» [9]. У теорії та практиці державного регулювання загальноприйнято, що центральний банк виконує функції нагляду, контролю й регулювання в банківській та монетарній системах, що закріплено у законодавчих актах. Однак у деяких країнах світу, в тому числі й в Україні, переконалися, що центральний банк не завжди виконує ці функції ефективно. 3 цих причин у багатьох європейських країнах його позбавили таких функцій, включаючи таргетування інфляціï, передавши цю справу єдиному органу нагляду й контролю за всіма фінансовими інституціями. Це досить глибокі зміни, що руйнують усталені порядки у грошово-фінансовій системі [9]. Аналізуючи ключові аспекти національної фінансової політики з нормативної точки зору, слід також відзначити, що основні аспекти питання фінансової безпеки відображені в Законі України «Про основи національної безпеки України» [1]. Це подолання «тінізації» економіки через реформування податкової системи, оздоровлення фінансово-кредитної сфери, зменшення позабанківського обігу грошової маси, забезпечення внутрішньої та зовнішньої захищеності національної валюти, їі стабільності, припинення відпливу капіталів за кордон, захист інтересів вкладників, виважена політика внутрішніх і зовнішніх запозичень.

\section{БІБЛІОГРАФІЯ}

1. Закон України від 19.06.2003 «Про основи національної безпеки України» №964-IV // zakon1.rada.gov.ua

2. Бєлєнький П., Другов О. Розвиток системи фінансових посередників України в умовах посилення глобалізаційних процесів // Вісник НБУ. - 2009. - № 12. - С. 30-33.

3. Лазепка В. Інвестиційні банки / В. Лазепка // Банківська справа. - 2010. - № 6 - С. 47-49.

4. Лукашевич В. М. Глобалистика / В. М. Лукашевич. - Львів : Новий світ-2000, 2004. - 227 с.

5. Лютий I., Дрозд Н. Вплив держави на ринок фінансового капіталу України // Фінанси Украї-
Висновки. У цілому державна політика у сфері підвищення ефективності функціонування фінансового ринку України повинна включати єдиний збалансований комплекс заходів, спрямованих на забезпечення стабільності та стійкості фінансової системи, ефективний контроль руху фінансових потоків, раціональне використання фінансових ресурсів.

Крім того, з огляду на об'єктивні тенденції сучасного фінансового ринку, необхідне формування адекватної середньо- та довгострокової фінансової політики на макрорівні. Державна фінансова політика повинна бути спрямована на вдосконалення ринкового ціноутворення і найбільш важливі для української економіки базові товари, забезпечення ефективності ринкової інфраструктури. У тому числі слід серйозну увагу приділити сегменту похідних фінансових інструментів фінансового ринку, підвищенню ефективності облікової системи, протидії спекулятивній практиці біржової торгівлі. Ефективне регулювання ринку деривативів потребує формування відповідних сучасних нормативноправових засад, принципів, стандартів і технологій регулювання учасників. Слід формувати державну фінансову політику 3 конкретною метою підвищення емісійної активності корпоративного сектора економіки, насамперед ринку акцій, що створить передумови капіталізації вітчизняного виробничого сектора.

ни. -2010 . - №8. - С. 63-72.

6. Управління міжнародною конкурентоспроможністю в умовах глобалізації економічного розвитку / Д.Г. Лук'яненко, А. М. Поручник [та ін.]. - К. : КНЕУ, 2011. - Т. 1. -816 с.

7. Фурман В. Перспективи створення альянсів страхових компаній і банків в Україні // Вісник НБУ. - 2012. - № 4. - С. 20-22.

8. Чухно A. Сучасна фінансово-економічна криза: природа, шляхи і методи іiі подолання // Економіка України. - 2011. - №2. - С. 4-13.

9. Шаро О. Але навіщо ж стільці ламати? // Дзеркало тижня. - 16.05.2009. 